\title{
Transport of circulating IGF-I and LR IGF-I from blood to extracellular wound fluid sites in rats
}

\author{
S E P Bastian, P E Walton and D A Belford \\ Cooperative Research Centre for Tissue Growth and Repair, PO Box 10065 Gouger Street, Adelaide, South Australia 5000, Australia \\ (Requests for offprints should be addressed to S E P Bastian)
}

\begin{abstract}
Significant levels of IGF-I are found in wound fluid. The contribution that systemic IGF-I makes to the total IGF-I pool in wounds and the influence of IGF binding proteins (IGFBPs) on the delivery of systemic IGF-I to these wound sites has not been established. In the present series of experiments, we have shown that IGF-I flux across a model endothelial cell barrier is decreased in the presence of IGFBPs, whereas flux of Long $\mathrm{R}^{3}$ IGF-I (LR ${ }^{3}$ IGF-I, an IGF-I analogue with low affinity for IGFBPs) is unaffected. On the basis of these findings, the transport of IGF-I and LR ${ }^{3}$ IGF-I from blood to extracellular wound fluid was assessed. Wound chambers were implanted subcutaneously in the backs of adult male rats and left in place for 14 days. A single i.v. bolus of either ${ }^{125}$ I-IGF-I or ${ }^{125}$ I-LR $^{3}$ IGF-I $\left(10 \times 10^{6}\right.$ c.p.m. $)$ was administered via a jugular catheter and wound fluid and plasma samples taken at sequential time points between 5 and $240 \mathrm{~min}$. ${ }^{125} \mathrm{I}-L R^{3} \mathrm{IGF}-\mathrm{I}$ was removed from the circulation more rapidly than ${ }^{125}$ I-IGF-I in both sham control and chamber implanted rats. Although implantation of the chambers did
\end{abstract}

not alter the pharmacokinetic parameters of ${ }^{125} \mathrm{I}-\mathrm{IGF}-\mathrm{I}$, significant increases in the steady state volume of distribution, clearance rate and half-life were recorded for ${ }^{125}$ I-LR ${ }^{3}$ IGF-I. In addition, significantly more intact ${ }^{125}$ I-LR ${ }^{3}$ IGF-I was recovered in wound fluid than ${ }^{125}$ I-IGF-I at each time point, although only $0.08 \%$ of administered ${ }^{125}{ }^{1-L R}{ }^{3}$ IGF-I was recovered per $\mathrm{ml}$ of wound fluid at $240 \mathrm{~min}$. Compared with plasma, a greater proportion of wound fluid IGF-I radioactivity had distributed to the lower molecular weight IGFBPs or existed as free peptide. However, a small amount of wound fluid ${ }^{125} \mathrm{I}-\mathrm{IGF}-\mathrm{I}$ was detected in the $150 \mathrm{kDa}$ region $30 \mathrm{~min}$ after injection. A greater proportion of ${ }^{125}$ I-LR ${ }^{3}$ IGF-I was associated with the lower molecular weight IGFBPs or existed as free peptide in both wound fluid and plasma. These data point to the importance of IGFBPs in determining the pharmacokinetic parameters of IGF-I in an extracellular fluid-expanded state. They also suggest only a minor role for endocrine IGF-I in surface wound repair. Journal of Endocrinology (2000) 164, 77-86

\section{Introduction}

The dual effector theory first suggested by Green et al. (1985) proposed that insulin-like growth factor-I (IGF-I) has both paracrine/autocrine and endocrine functions. Since IGF activity has been detected in tissue extracts and media conditioned by many cell types, investigations have focused principally on the possible paracrine/autocrine nature of IGF-I. However, evidence has also been accumulating to suggest that IGF-I of endocrine origin promotes growth of kidney, lung, thymus and spleen (Schoenle et al. 1982, Zapf et al. 1985, Guler et al. 1988, Glassock et al. 1991). Additionally, IGF-I acting in the classical endocrine fashion promotes formation and repair of bone (Ebeling et al. 1993), stimulates body protein and glucose metabolism (Jacob et al. 1989) and increases glomerular filtration rate and renal plasma flow (Guler et al. 1989). For IGF-I to exert its action in an endocrine manner, it must first leave the blood by traversing the endothelial cell barrier. IGF-I is able to cross intact endothelium and capillaries (Bar et al. 1990a,c, Boes et al. 1992, Taylor et al. 1993, Bastian et al. 1997) and it has been demonstrated that IGF-I transfers passively across a human umbilical vein endothelial (HUVE) cell monolayer by a non-receptor mediated pathway (Bastian et al. 1997). Additionally, several in vivo studies have shown that both IGF-I and its analogue LR $^{3}$ IGF-I are able to leave the vascular compartment and distribute to many different tissues (Cascieri et al. 1988, Ballard et al. 1991, Bastian et al. 1993, Hill et al. 1997).

In vivo, IGF-I circulates in the blood complexed to multiple specific binding proteins. The role of IGFBPs in the transfer of IGF-I from blood to tissues is still not well understood. Association of IGF-I with the lower molecular weight IGFBPs is thought to permit targeting of specific tissues (Sara \& Hall 1990). In support of this, IGF binding proteins IGFBP-1, IGFBP-2, IGFBP-3 and IGFBP-4 have all displayed the ability to traverse the capillary barrier in the perfused isolated beating rat heart (Bar et al. 1990b,c, Boes et al. 1992). More recently, radiolabeled 
recombinant human IGFBP-3 not associated with the ternary complex has been shown to rapidly cross capillary endothelia from blood to extracellular sites including kidney, liver and gastrointestinal tissues, supporting a role for IGFBP-3 in the delivery of IGF-I to peripheral tissues (Arany et al. 1993).

The majority of IGF-I is present in the circulation associated with IGFBP-3, which together with an acidlabile subunit forms a ternary complex of $150 \mathrm{kDa}$ (Baxter 1988). The discovery of increased protease activity for circulating IGFBP-3 occurring in pregnancy, postsurgery, cancer, critical illness, renal failure and HIV infection has led to the proposal that the ternary complex may serve as a readily releasable pool of IGFs in blood available during stress (Davenport et al. 1990, 1992, Cwyfan Hughes et al. 1992, Frost et al. 1993, 1996, Lee et al. 1994, Timmins et al. 1996). That is, an increase in enzymatically processed IGFBP-3 with weaker affinity for IGF-I than intact IGFBP-3 could increase the ease of release of IGF-I from the complex and in turn enhance the tissue bioavailability of IGF-I (Holly et al. 1993, Lamson et al. 1993).

As a first step in understanding how IGFBPs may affect the translocation of IGFs from plasma to extracellular wound fluid, we used an in vitro model of an endothelial cell barrier and examined the effects of the addition of exogenous IGFBPs on the transport of IGF-I across the endothelial cell monolayer. The Hunt-Schilling chamber was originally designed to study respiratory gas tensions in healing wounds (Hunt et al. 1967). This model offers a site of readily accessible extracellular wound fluid, free of blood contamination. The current experiments aimed to examine the delivery of IGF-I from the vasculature to extracellular wound fluid in vivo using the Hunt-Schilling chambers. The use of LR ${ }^{3}$ IGF-I in parallel experiments, permitted investigation of the effects of IGFBPs on this delivery.

\section{Materials and Methods}

\section{Materials}

IGFBPs used in these studies were generously supplied by the following: human IGFBP-1, Diagnostic Systems Laboratories (Webster, TX, USA); human IGFBP-2, Dr Eiji Kuto (Basel, Switzerland); human IGFBP-3 and IGFBP-6, Dr Robert Baxter (Sydney, Australia) and human IGFBP-4, IGFBP-5 and truncated IGFBP-5 (tIGFBP-5), Dr Dennis Andress (Seattle, WA, USA). Recombinant human IGF-I and recombinant LR $^{3}$ IGF-I were purchased from GroPep Pty. Ltd (Adelaide, Australia). Both peptides were iodinated with carrier free $\mathrm{Na}^{125} \mathrm{I}$ from Amersham (Buckinghamshire, UK) to a specific activity of $85 \mu \mathrm{Ci} / \mu \mathrm{g}$ using a modification of the chloramine T method (Gargosky et al. 1990). [ $\left.{ }^{3} \mathrm{H}\right]$ Inulin was also obtained from Amersham. Heparin and BSA were purchased from Sigma (St Louis, MO, USA). Trichloroacetic acid (TCA) was from BDH Chemicals (Victoria, Australia). Methohexitone sodium was from Eli Lilly (West Ryde, NSW, Australia) and pentobarbitone sodium was from Boehringer Ingelheim Pty Ltd (Smithfield, NSW, Australia).

\section{Cell culture and transmigration studies}

Human umbilical vein endothelial (HUVE) cells were isolated from the vein of 12-24 h old umbilical cords and used to perform transmigration studies as described in Bastian et al. (1997). Prior to addition of ${ }^{125} \mathrm{I}-\mathrm{IGF}-\mathrm{I}$ or ${ }^{125} \mathrm{I}-\mathrm{LR}^{3} \mathrm{IGF}-\mathrm{I}$ to the luminal chamber at time zero, each labeled IGF was incubated for $2 \mathrm{~h}$ at $37^{\circ} \mathrm{C}$ with a 1:1 molar amount of either hIGFBP-1, $-2,-3,-4,-5,-6$ or truncated hIGFBP-5. At 5 min following the addition of the labeled IGF-IGFBP mix to the luminal chamber, a sub-sample $(100 \mu \mathrm{l})$ was taken from the abluminal chamber which was immediately replenished with the same amount of fresh media. Further sub-samples were collected at 30, 60 and $120 \mathrm{~min}$. Transmigrated ${ }^{125} \mathrm{I}-\mathrm{IGF}-\mathrm{I}$ and ${ }^{125} \mathrm{I}-\mathrm{LR}^{3} \mathrm{IGF}-\mathrm{I}$ were measured as TCA-precipitable radioactivity. $\left[{ }^{3} \mathrm{H}\right]$ inulin is impermeable to cell membranes and was used as a marker of intercellular leakage.

\section{Animals and implantation of Hunt-Schilling wound chambers}

Twenty male Sprague-Dawley rats with a mean weight \pm S.E.M of $472 \cdot 6 \pm 11 \cdot 1 \mathrm{~g}$ were obtained from the Central Animal House, University of Adelaide. All experimental protocols were approved by both the University of Adelaide Animal Ethics Committee and The Women's and Children's Hospital Ethics Committee.

Stainless steel Hunt-Schilling wound chambers $3 \mathrm{~cm}$ long by $1 \mathrm{~cm}$ in diameter (Schilling et al. 1959, Hunt et al. 1967) were constructed from no. 40 mesh and the ends plugged with silicon polymer. Chambers were washed in ethanol, rinsed several times with distilled water and autoclaved. Rats were anesthetized with isoflurane and an oxygen-nitrous oxide mix. Four $1 \mathrm{~cm}$ abaxial incisions were made, one either side of the midline at a point just craniad to the sacrum and one either side of the midline at the sacrum, permitting creation of four subcutaneous pockets by blunt dissection for implantation of chambers. Each chamber was introduced using a modified $5 \mathrm{ml}$ syringe craniad to each incision and finally located in a dorso-lateral orientation. The incisions were sutured with non-absorbable material. Implantations were performed using aseptic technique. Eight of the 20 rats acted as sham controls and were not implanted with wound chambers. The animals were kept warm until conscious and allowed to recover with free access to food and water for 14 days prior to experimentation. Preliminary experiments have shown that, by day 14 , the chambers are encapsulated by vascularized granulation tissue that comes into close contact with the wound fluid. 


\section{Experimental procedures}

Two days prior to experimentation, all animals were anesthetized by an i.p. injection of a 9:1 solution of methohexitone sodium and pentobarbitone sodium $(3.75 \mathrm{ml} / \mathrm{kg}$ of body weight) and a catheter inserted into the jugular vein. The animals were kept warm until conscious, and allowed free access to food and water and left to recover for two days. On the experimental day, rats had a mean weight \pm S.E.M. of $481 \cdot 0 \pm 9.5$ g. Prior to infusion of radiolabeled IGFs, a $200 \mu$ l blood sample was withdrawn from the catheter of each rat. Following each blood sampling, the equivalent volume of saline containing 10 IU heparin was injected back into the catheter line. Blood samples were collected into tubes heparinized to a final concentration of $10 \mathrm{IU} / \mathrm{ml}$ and centrifuged for $2 \mathrm{~min}$ at $10000 \mathrm{~g}$ at room temperature. Plasma was removed, frozen in liquid nitrogen and stored at $-20{ }^{\circ} \mathrm{C}$ for Western ligand blot analysis. Rats were randomly chosen for infusion with either ${ }^{125}$ I-IGF-I or ${ }^{125}$ I-LR $^{3}$ IGF-I. At time zero, each rat received a bolus dose $(100 \mu \mathrm{l})$ of $10 \times 10^{6}$ c.p.m. of ${ }^{125} \mathrm{I}-\mathrm{IGF}-\mathrm{I}$ or ${ }^{125} \mathrm{I}_{-\mathrm{LR}}{ }^{3} \mathrm{IGF}-\mathrm{I}$ in physiological saline plus $0.01 \%$ BSA via the jugular catheter, and the catheter line was flushed with $300 \mu \mathrm{l}$ of saline. Blood samples of $150 \mu \mathrm{l}$ were withdrawn at 1,15 , 60 and $180 \mathrm{~min}$ for TCA precipitation analyses, while $300 \mu \mathrm{l}$ blood samples were collected at 5, 30, 120 and $240 \mathrm{~min}$ for TCA precipitation analyses and FPLC. At 5, 30,120 and $240 \mathrm{~min}$, one of the four wound chambers was aspirated of its fluid contents by percutaneous insertion of a 19 gauge needle through the silicon plug. Care was taken to avoid damaging the granulation tissue on the inner surface of the chamber to prevent contamination of wound fluid with blood. Wound fluid from each chamber was collected into separate tubes, heparinized to a final concentration of $10 \mathrm{IU} / \mathrm{ml}$ and centrifuged at $10000 \mathrm{~g}$ for $2 \mathrm{~min}$ at room temperature. Supernatant was aliquotted into tubes, frozen in liquid nitrogen and stored at $-20{ }^{\circ} \mathrm{C}$.

Trichloroacetic acid precipitation of ${ }^{125}$ I-IGF-I and

${ }^{125} \mathrm{I}-L R^{3} \mathrm{IGF}-\mathrm{I}$ in plasma and wound fluid samples

Duplicate portions of plasma $(25 \mu \mathrm{l})$ and wound fluid $(50 \mu \mathrm{l})$ from each rat and wound chamber were counted in a $\gamma$-counter for $10 \mathrm{~min}$. Plasma and wound fluid samples were then mixed with $475 \mu \mathrm{l}$ and $450 \mu \mathrm{l}$ of ice-cold $10 \%$ $(\mathrm{v} / \mathrm{v})$ TCA in PBS plus $0 \cdot 1 \%(\mathrm{w} / \mathrm{v})$ BSA respectively. Samples were incubated on ice for $2 \mathrm{~h}$ then centrifuged at $4{ }^{\circ} \mathrm{C}$ for $20 \mathrm{~min}$ at $10000 \mathrm{~g}$. The supernatant was removed and the radioactivity in both the TCA-soluble and TCAinsoluble portions measured in a $\gamma$-counter for $10 \mathrm{~min}$.

\section{Neutral gel permeation chromatography}

Pools of time 5, 30, 120 and 240 min plasma $(200 \mu \mathrm{l})$ and wound fluid $(150 \mu \mathrm{l})$ samples from chamber-implanted rats infused with ${ }^{125} \mathrm{I}-\mathrm{IGF}-\mathrm{I}$ or ${ }^{125} \mathrm{I}-\mathrm{LR}{ }^{3} \mathrm{IGF}-\mathrm{I}$, and plasma samples $(200 \mu \mathrm{l})$ from sham controls infused with ${ }^{125} \mathrm{I}-$

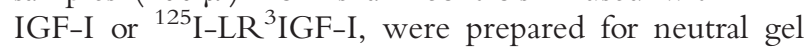
permeation chromatography. Wound fluid was first centrifuged at $4{ }^{\circ} \mathrm{C}$ at $10000 \mathrm{~g}$ for $5 \mathrm{~min}$ to remove solids. Lipids were removed from both the plasma and wound fluid samples by extraction with Freon $(1,1,2$ trichloro-1,2,2-trifluorethane) then chromatographed on a Superose-12 column (HR 10/30), as previously described in Bastian et al. (1993).

\section{Western ligand blot analysis}

To examine the plasma IGFBP profiles of rats implanted with chambers compared with those of the sham control animals, $10 \mu \mathrm{l}$ samples of blood collected from each rat before radiolabeled IGF infusion were mixed with $190 \mu \mathrm{l}$ of SDS-loading buffer and incubated for $15 \mathrm{~min}$ at $65^{\circ} \mathrm{C}$. Rat plasma samples ( $1 \mu \mathrm{l}$ equivalence) were subjected to SDS-PAGE, proteins were transferred to nitrocellulose sheets using a Multiphor II NovaBlot electrophoretic unit and IGFBPs detected as described in Bastian et al. (1993). Nitrocellulose sheets were probed with either $5 \times$ $10^{5}$ c.p.m. of ${ }^{125}$ I-IGF-I or ${ }^{125}$ I-LR ${ }^{3}$ IGF-I and exposed to $\mathrm{X}$-ray film for 4 days.

\section{Pharmacokinetic analysis}

Pharmacokinetic parameters for each rat were calculated by fitting the data to a bi-exponential equation that describes a two-compartment model with utilization of a non-linear curve-fitting program (Tablecurve Windows V1.0; Jandel Scientific, Corte Madera, CA, USA) in which $C=A \mathrm{e}^{-a t}+B \mathrm{e}^{-\beta t}$, where $C$ equals the plasma concentration of TCA-precipitable radioactivity per milliliter; $A$ and $B$ correspond to the concentrations of TCAprecipitable radioactivity in each compartment at time $0 ; a$ and $\beta$ are the decay rate constants for each compartment and $t$ is time. The area under the curve (AUC) method was used to determine total plasma clearance (CL) using the relationship $\mathrm{CL}=$ dose/AUC, where the dose equals IGF radioactivity administered. Initial volume of distribution $\left(V_{\mathrm{c}}\right)$ was calculated as $V_{\mathrm{c}}=\operatorname{dose} /(A+B)$. The volume of distribution at steady state $\left(V_{\mathrm{ss}}\right)$ was calculated as $V_{\mathrm{ss}}=\left(A / \alpha^{2}+B / \beta^{2}\right) /$ AUC.

\section{Statistical analyses}

All statistical analyses were performed using SigmaStat for Windows statistical software from Jandel Scientific (San Rafael, CA, USA). Transmigration data and appearance of TCA-precipitable IGFs in extracellular fluid were analyzed by one-way analysis of variance with all pair-wise multiple comparisons using Student-Newman-Keuls method. Pharmacokinetic data was analyzed by two-way analysis of variance with replications on two main factors: 
growth factor and chamber status. $P<0 \cdot 05$ was considered significant.

\section{Results}

Effect of IGFBPs on transport of ${ }^{125} I-I G F-I$ and ${ }^{125} I-L R^{3} I G F-I$ across HUVE cell monolayers

To examine whether IGFBPs have an effect on IGF-I transport across endothelial cell barriers, the transport of ${ }^{125} \mathrm{I}-\mathrm{IGF}-\mathrm{I}(8 \mathrm{ng})$ and ${ }^{125} \mathrm{I}-\mathrm{LR}^{3} \mathrm{IGF}-\mathrm{I}(8 \mathrm{ng})$ was examined in the presence of IGFBPs. These experiments were carried out at a 1:1 molar ratio of ${ }^{125}$ I-IGF-I:IGFBP. With the exception of truncated hIGFBP-5, which has a greatly reduced affinity for IGF-I (Andress \& Birnbaum 1992), each of the IGFBPs significantly inhibited the transport of ${ }^{125}$ I-IGF-I from the luminal to abluminal chamber (Fig. 1a). In contrast, when ${ }^{125}{ }^{2}-\mathrm{LR}^{3}$ IGF-I was the labeled ligand under examination (Fig. 1b), there was no inhibition of transport of this peptide, confirming that the IGFBPs inhibit transport by binding to free IGF-I. No difference in transport between inulin and IGF-I was seen as determined in earlier studies (Bastian et al. 1997). However, LR ${ }^{3}$ IGF-I transport was significantly lower than that of inulin.

Comparison of IGFBP profiles in plasma of wound chamber-implanted and sham control rats

To examine whether the implantation of chambers in rats caused a perturbation of the plasma IGFBP profile which could potentially alter the transport of IGFs from blood to extracellular fluid sites, Western ligand blot analysis of implanted and sham control pooled rat plasma was performed. In both implanted and sham control pooled rat plasma, a doublet of bands at approximately $46-50 \mathrm{kDa}$ (IGFBP-3), along with two fainter lower molecular weight bands of similar intensity at 31 and $24 \mathrm{kDa}$ were observed when ${ }^{125}$ I-IGF-I was the radiolabeled ligand (Fig. 2). Laser scanning densitometry showed no significant difference between the intensity of the IGFBP-3 band in the chamber-implanted (103 \pm 8.4 OD units; mean \pm S.D., $n=6)$ and sham control rats $(105 \pm 10$ OD units; mean \pm s.D., $n=4)$. When ${ }^{125}$ I-LR $^{3}$ IGF-I was the radiolabeled probe, a faint band at $46 \mathrm{kDa}$ was seen in both wound chamber-implanted and sham control rat plasma pools, confirming the weaker affinity of the IGF-I analogue for rat plasma IGFBPs.

\section{Pharmacokinetic parameters of ${ }^{125}$ I-IGF-I and \\ ${ }^{125}$ I-LR ${ }^{3} I G F-I$ in wound chamber-implanted and sham control rats}

Clearance studies were performed to determine whether the implantation of wound chambers affected the clearance
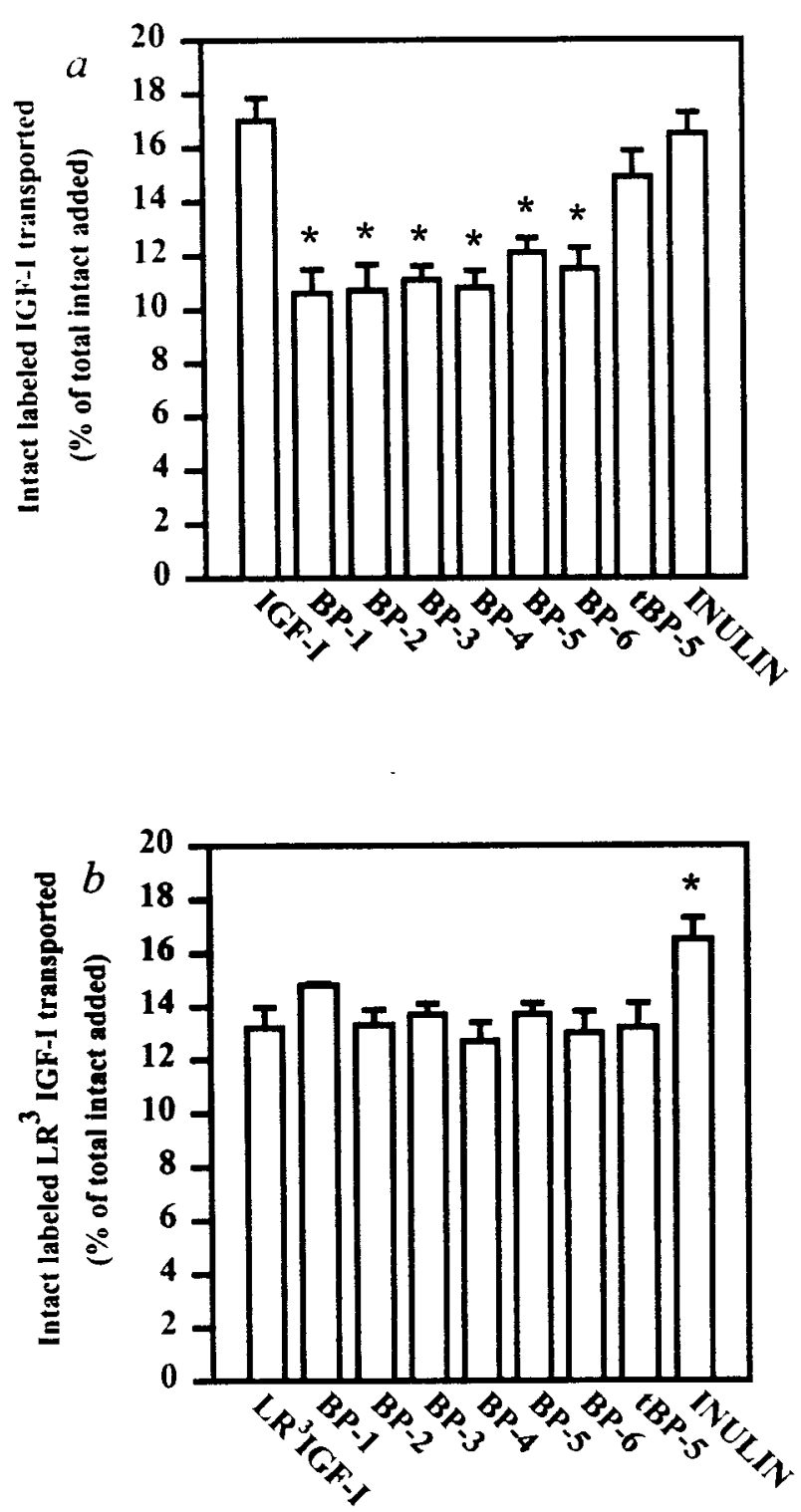

Figure 1 Effects of IGFBPs on the transport of ${ }^{125}$ I-IGF-I and ${ }^{125}$ I-LR ${ }^{3}$ IGF-I across HUVE cell monolayers. ${ }^{125}$ I-IGF-I (a) and

${ }^{125}$ I-LR ${ }^{3}$ IGF-I (b) transport is shown as a percentage of total intact labeled IGF added to the luminal chamber at time zero, appearing in the abluminal chamber at $2 \mathrm{~h}$. Labeled IGF transport across HUVE cell monolayers was measured in the presence of a $1: 1$ molar ratio of either hIGFBP-1, -2, -3, -4, -5, -6 or truncated hIGFBP-5. Data represents the pooled means \pm S.E.M. of triplicate transwells from three experiments. ${ }^{*}$ Significant differences in transport with respect to either ${ }^{125}$ I-IGF-I or ${ }^{125}$ I-LR ${ }^{3}$ IGF-I across HUVE cell monolayers $(P<0 \cdot 05)$.

values of IGFs in rats. The mean TCA-precipitable radioactivity in plasma over time is shown in Fig. 3. In all cases an early rapid and subsequent slower decline in plasma concentration of the labeled growth factors was observed. The area under the curves defining the rapid $(\alpha)$ and slower 


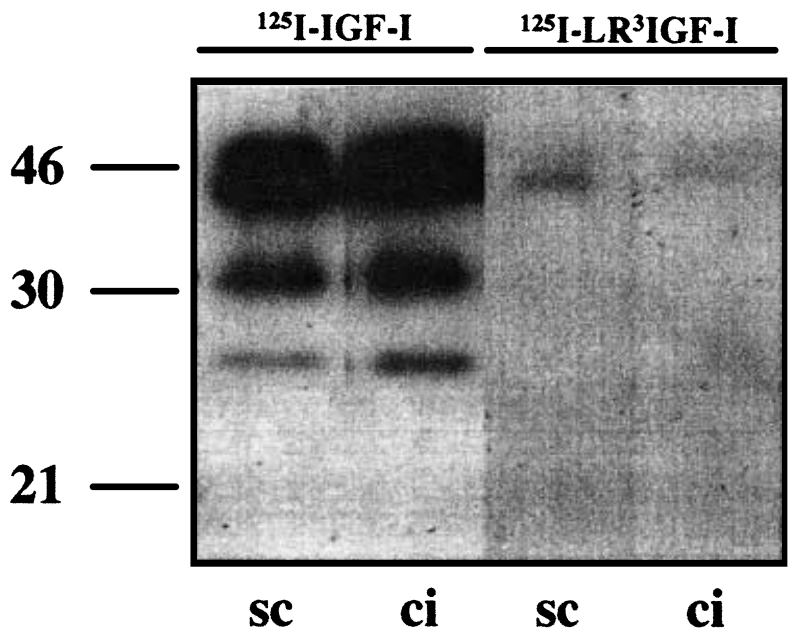

Figure 2 Western ligand blots of day 14 plasma from sham control and chamber-implanted rats. Plasma ( $1 \mu \mathrm{l}$ equivalence) from representative sham control (sc) and chamber-implanted (ci) rats prior to infusion of labeled IGF-I or LR ${ }^{3}$ IGF-I were added to SDS-sample buffer and electrophoresed on 12.5\% SDS-PAGE gels under non-reducing conditions. The proteins were transferred to nitrocellulose sheets and incubated with $5 \times 10^{5}$ c.p.m. of either ${ }^{125}$ I-IGF-I or ${ }^{125}$ I-LR ${ }^{3}$ IGF-I, and exposed to X-ray film for 4 days. The positions of molecular mass markers (in $\mathrm{kDa}$ ) are indicated.

(B) components are shown in Fig. 3. The clearance, half-lives of the rapid and slower components plus initial and steady state volumes of distribution are presented in Table 1. Half-lives for the fast component of both ${ }^{125} \mathrm{I}-$ IGF-I and ${ }^{125}$ I-LR ${ }^{3}$ IGF-I were significantly greater for chamber-implanted animals compared with controls. The area under the curve for the fast component of ${ }^{125}$ I-IGF-I infused chamber-implanted animals was significantly decreased relative to sham control IGF-I infused and chamber-implanted LR ${ }^{3}$ IGF-I infused rats. For the slower phase, the area under the curve was significantly greater for ${ }^{125}$ I-IGF-I than ${ }^{125}$ I-LR $^{3}$ IGF-I in both sham control and chamber-implanted rats. This indicates that $\mathrm{LR}^{3} \mathrm{IGF}-\mathrm{I}$ radioactivity is cleared more rapidly and that the amount of $\mathrm{LR}^{3}$ IGF-I radioactivity in the slow pool is reduced. This is reflected in the metabolic clearance rate of ${ }^{125} \mathrm{I}-\mathrm{IGF}-\mathrm{I}$, which was significantly reduced, being $2 \cdot 3$-fold and $2 \cdot 5-$ fold lower than ${ }^{125} \mathrm{I}_{-} \mathrm{LR}^{3} \mathrm{IGF}-\mathrm{I}$ in sham control and chamber-implanted rats, respectively. Additionally, the half-lives of IGF-I were significantly greater than LR $^{3}$ IGF-I for the slow component. For LR ${ }^{3}$ IGF-I in chamber-implanted rats, the area under the curve and the half-life of the slow component were significantly higher than that obtained in sham controls. However, the steady state volume of distribution for LR $^{3}$ IGF-I was much higher in chamber-implanted rats which is reflected in a higher metabolic clearance rate. Steady state volumes of distribution were larger for LR $^{3}$ IGF-I than IGF-I, which indicates that more IGF-I is confined to the circulation, as

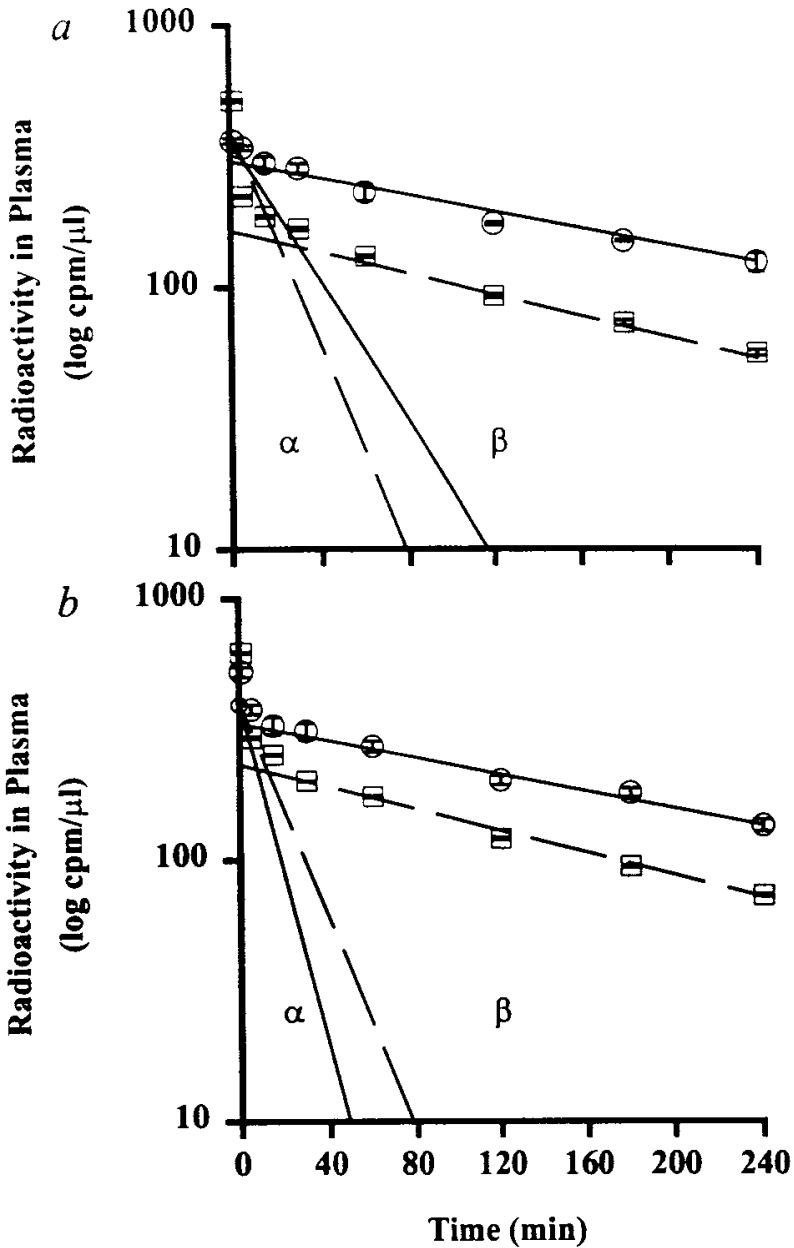

Figure 3 Clearance of TCA-insoluble radioactivity from plasma of (a) sham control and (b) wound chamber-implanted rats following injection of either ${ }^{125} \mathrm{I}$-IGF-I (circles and solid lines) or ${ }^{125}$ I-LR ${ }^{3}$ IGF-I (squares and dashed lines) at time zero. Values are means \pm S.E.M. for six animals in chamber-implanted groups and four animals in sham control groups. Decay curves were calculated as described in the Materials and Methods.

expected on the basis of the differences between these two peptides in binding to plasma IGFBPs. These results showed that ${ }^{125}$ I-LR ${ }^{3}$ IGF-I was removed from the circulation more rapidly than ${ }^{125}$ I-IGF-I in both control and chamber-implanted animals. ${ }^{125}$ I-IGF-I in sham control and chamber-implanted rats is cleared with similar kin-

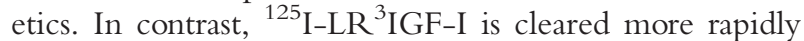
in chamber-implanted rats, reflecting the larger volume of distribution for this peptide in these animals.

Appearance and TCA-precipitability of ${ }^{125}$ I-IGF-I and ${ }^{125}$ I-LR ${ }^{3}$ IGF-I in wound fluid following infusion via a jugular catheter

To determine whether IGFBPs affect the transfer of IGF-I from blood to extracellular fluid sites, the appearance of 
Table 1 Pharmacokinetic parameters for labeled IGF-I and LR IGF-I administered to wound chamber-implanted (ci) and sham control (sc) rats. Values are means \pm S.E.M. for four animals in each sham control group and six animals in each wound chamber-implanted group. $V_{\mathrm{C}}$ and $V_{\mathrm{ss}}$ are the initial and steady state volumes of distribution, respectively. $t_{1 / 2 \alpha}$ and $t_{1 / 2 \beta}$ are the half-lives for the rapid and slow component respectively

\begin{tabular}{|c|c|c|c|c|c|}
\hline & \multirow{2}{*}{$\begin{array}{l}\text { Clearance } \\
(\mathrm{ml} / \mathrm{min} \text { per } \mathrm{kg})\end{array}$} & \multicolumn{2}{|c|}{$\begin{array}{l}\text { Volume of distribution } \\
(\mathrm{ml} \text { per } \mathrm{kg})\end{array}$} & \multicolumn{2}{|l|}{$\begin{array}{l}\text { Half-lives } \\
(\mathrm{min})\end{array}$} \\
\hline & & $V_{\mathrm{c}}$ & $V_{\mathrm{ss}}$ & $t_{1 / 2 \alpha}$ & $t_{1 / 2 \beta}$ \\
\hline IGF-I (ci) & $0 \cdot 4 \pm 0 \cdot 01$ & $62 \cdot 4 \pm 3 \cdot 2$ & $101 \cdot 4 \pm 5 \cdot 6$ & $4.9 \pm 0.02$ * & $185 \cdot 4 \pm 4 \cdot 7$ \\
\hline LR $^{3}$ IGF-I (sc) & $0.7 \pm 0.02 *$ & $70 \cdot 8 \pm 0 \cdot 6$ & $109 \cdot 1 \pm 4 \cdot 6^{*}$ & $2 \cdot 8 \pm 0 \cdot 1$ & $111 \cdot 1 \pm 3 \cdot 9^{*}$ \\
\hline LR $^{3}$ IGF-I (ci) & $1 \cdot 0 \pm 0.03 \ddagger^{* *}$ & $78 \cdot 7 \pm 7 \cdot 1$ & $197 \cdot 2 \pm 6 \cdot 9 \ddagger^{* *}$ & $4 \cdot 6 \pm 0 \cdot 5 \ddagger$ & $140 \cdot 2 \pm 2 \cdot 5 \ddagger^{* *}$ \\
\hline
\end{tabular}

${ }^{*} P<0.05$ compared with IGF-I sham control.

$* * P<0.05$ compared with IGF-I chamber-implanted rats.

$\ddagger P<0 \cdot 05$ compared with LR ${ }^{3}$ IGF-I sham control.

both ${ }^{125}$ I-IGF-I and ${ }^{125}$ I-LR ${ }^{3}$ IGF-I in wound fluid was examined following systemic infusion of these peptides into rats implanted with wound chambers. Five minutes following infusion of ${ }^{125} \mathrm{I}-\mathrm{IGF}-\mathrm{I}$ into rats, $0 \cdot 003 \pm 0 \cdot 001 \%$ (mean \pm S.E.M, $n=6$ ) of total infused, intact ${ }^{125} \mathrm{I}-\mathrm{IGF}-\mathrm{I}$ had appeared per milliliter of wound fluid. By $240 \mathrm{~min}$, this figure had increased up to $0 \cdot 05 \pm 0 \cdot 004 \%$ (Fig. 4). This intact radioactivity represented $35 \cdot 7 \pm 1 \cdot 7 \%$ (mean \pm S.E.M: $n=6), 32 \cdot 8 \pm 0 \cdot 5 \%, 21 \cdot 3 \pm 0 \cdot 6 \%$ and $20 \cdot 0 \pm 0 \cdot 9 \%$ of total radioactivity in wound fluid at $5,30,120$ and $240 \mathrm{~min}$ respectively. In contrast, significantly more

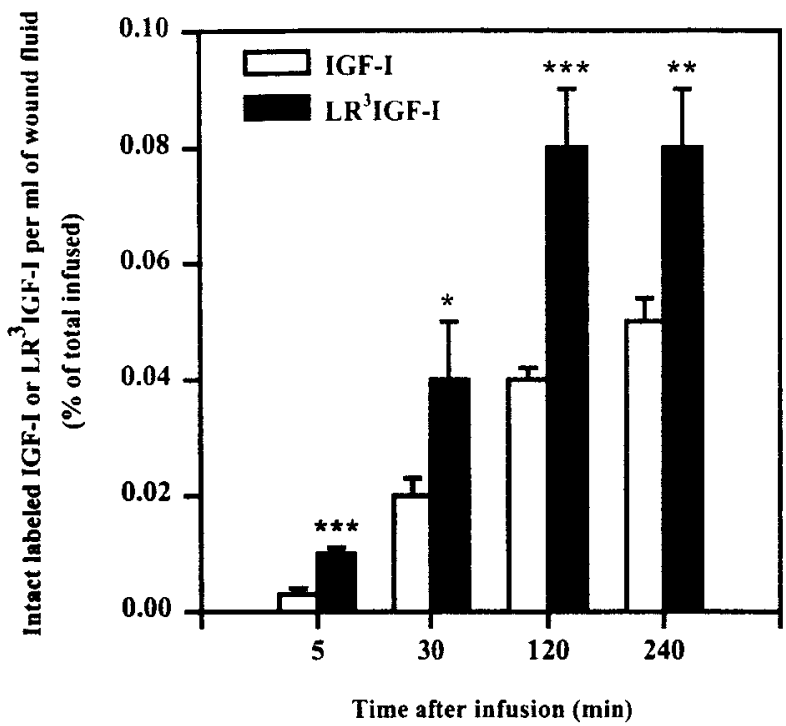

Figure 4 Appearance of TCA-precipitable (intact) ${ }^{125}$ I-IGF-I or ${ }^{125}$ I-LR ${ }^{3}$ IGF-I in day 14 wound fluid as a percentage of total intact infused ${ }^{125}$ I-IGF-I or ${ }^{125}$ I-LR ${ }^{3}$ IGF-I. Wound fluid from one chamber from each rat was collected at 5, 30, 120 and 240 min following infusion of labeled growth factors. Values represent the mean \pm S.E.M. of samples from one chamber per rat from six rats at each time point. ${ }^{*} P<0 \cdot 05,{ }^{*} P<0 \cdot 01$ and ${ }^{* *}{ }^{*} P<0 \cdot 001$ represent significant differences in appearance of ${ }^{125} I-L^{3} \mid G F-I$ in wound fluid compared with that of ${ }^{125}$ I-IGF-I.
${ }^{125}$ I-LR ${ }^{3}$ IGF-I than ${ }^{125}$ I-IGF-I was recovered per milliliter of wound fluid at each time point (Fig. 4). At $5 \mathrm{~min}$ $0 \cdot 01 \pm 0 \cdot 001 \%$ (mean \pm S.E.M, $n=6, \quad P<0 \cdot 001$ ) of total infused intact ${ }^{125} \mathrm{I}-\mathrm{LR}^{3} \mathrm{IGF}-\mathrm{I}$ had appeared per milliliter of wound fluid. By $240 \mathrm{~min}$ the amount had increased to $0 \cdot 08 \pm 0 \cdot 01 \%(n=6, P<0 \cdot 01)$. These data indicate that the egress of ${ }^{125}$ I-IGF-I from blood to extracellular wound fluid sites is impeded relative to ${ }^{125}$ I-LR ${ }^{3}$ IGF-I. The total amount of radioactivity in wound fluid of rats infused with ${ }^{125}$ I-LR ${ }^{3}$ IGF-I was $40 \cdot 3 \pm 2 \cdot 0 \%, 31 \cdot 8 \pm 2 \cdot 1 \%, 21 \cdot 7 \pm$ $1 \cdot 3 \%$ and $18 \cdot 4 \pm 1 \cdot 3 \%$ TCA precipitable at 5, 30, 120 and $240 \mathrm{~min}$ respectively.

\section{Profiles of IGF radioactivity in plasma and wound fluid}

Pooled plasma samples from six animals sampled 5 min after infusion with ${ }^{125}$ I-IGF-I chromatographed as a broad region of radioactivity at $150 \mathrm{kDa}$, a second at approximately $50 \mathrm{kDa}$ and a third minor peak at the position corresponding to the molecular mass of free IGF-I (Fig. 5). By $30 \mathrm{~min}$ the radioactivity of each region had slightly decreased. At $120 \mathrm{~min}$ the radioactivity of the 150,50 and $7.5 \mathrm{kDa}$ regions has decreased by approximately $50 \%$, with a further reduction in the high molecular mass region evident by $240 \mathrm{~min}$. At each time point a preferential decrease of IGF radioactivity associated with low molecular weight IGFBPs was observed.

The chromatograms of pooled plasma samples after administration of ${ }^{125} \mathrm{I}-\mathrm{LR}^{3} \mathrm{IGF}-\mathrm{I}$ are shown in Fig. 5. Unlike IGF-I radioactivity in plasma, less total counts were observed and approximately $40 \%$ of the radioactivity in these samples was detected as free ${ }^{125}$ I-LR ${ }^{3}$ IGF-I with much lower amounts appearing in the $150 \mathrm{kDa}$ and $50 \mathrm{kDa}$ regions. Radioactivity collected in fractions corresponding to free IGF peptide was cleared more quickly than radioactivity in higher molecular weight peaks. By $30 \mathrm{~min}$ the radioactivity in the $7.5 \mathrm{kDa}$ region had decreased by $50 \%$, while the radioactivity in the $150 \mathrm{kDa}$ and $50 \mathrm{kDa}$ regions evident at $5 \mathrm{~min}$ remained 


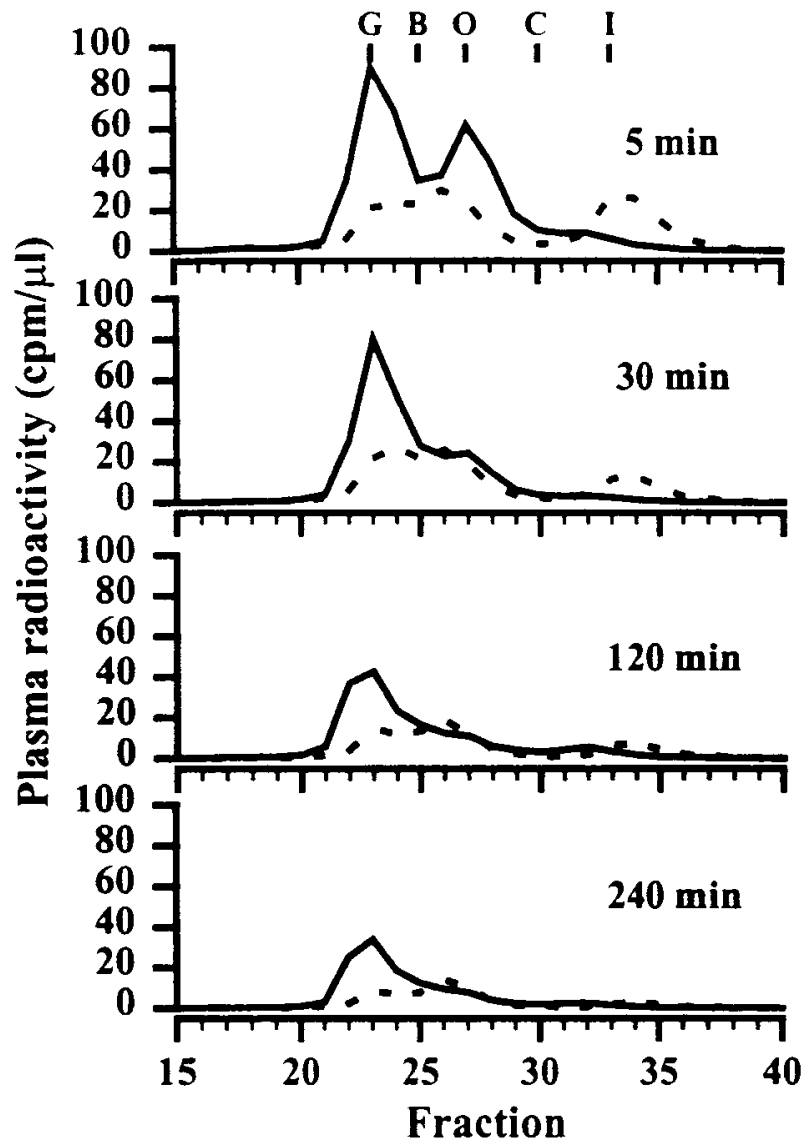

Figure 5 Neutral gel permeation chromatography of plasma from rats 5, 30, 120 and $240 \mathrm{~min}$ after an intravenous bolus of ${ }^{125}$ I-IGF-I (solid lines) or ${ }^{125}$ I-LR ${ }^{3}$ IGF-I (dashed lines). Pools of plasma from six rats $(200 \mu \mathrm{l})$ were mixed and applied to a Superose-12 column equilibrated in PBS $(\mathrm{pH} 7 \cdot 2)$. Samples were eluted at $0.5 \mathrm{ml} / \mathrm{min}$ with the same buffer. The column was calibrated with $\gamma$-globulin (G, $150 \mathrm{kDa}), \mathrm{BSA}(\mathrm{B}, 66 \mathrm{kDa})$, ovalbumin $(\mathrm{O}, 43 \mathrm{kDa})$, carbonic anhydrase $(\mathrm{C}, 30 \mathrm{kDa})$ and ${ }^{125}$ I-IGF-I (I, $\left.7 \cdot 5 \mathrm{kDa}\right)$. Fractions $(0.5 \mathrm{ml})$ were collected and radioactivity counted on a $\gamma$-counter. Values per microliter of plasma are shown.

approximately the same. At 120 and $240 \mathrm{~min}$ the radioactivity in each of the three regions continued to decrease at a relatively similar rate.

In contrast to plasma, less radioactivity was contained within wound fluid following infusion of labeled IGFs. It is important to note the difference in scale of the $y$-axis for the plasma chromatography profiles (Fig. 5), compared with the scale of the $y$-axis for the wound fluid chromatography profiles (Fig. 6). Pooled wound fluid samples from six animals sampled at 5 min following infusion of ${ }^{125}$ I-IGF-I chromatographed as a broad region at approximately $50 \mathrm{kDa}$ and a peak at the position corresponding to free IGF-I (Fig. 6). By $30 \mathrm{~min}$ the radioactivity in the $7 \cdot 5 \mathrm{kDa}$ region had decreased slightly, however a third

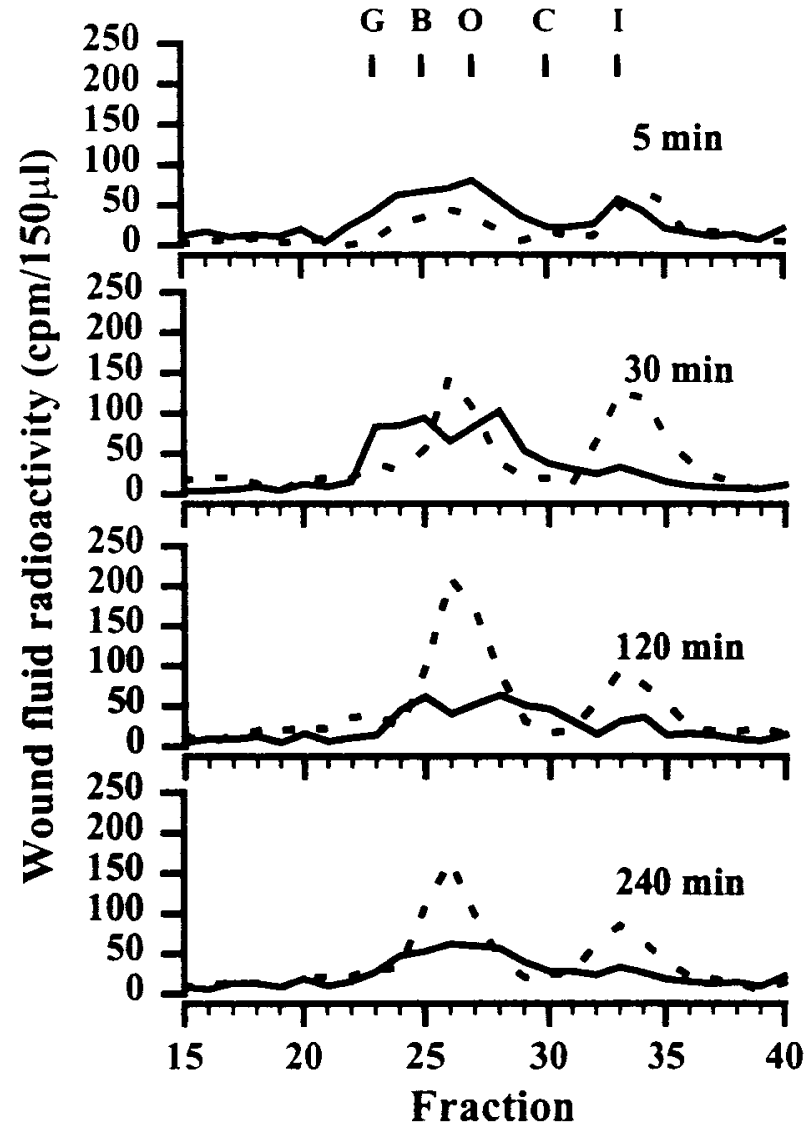

Figure 6 Neutral gel permeation chromatography of wound fluid from rats 5, 30, 120 and 240 min after an intravenous bolus of ${ }^{125}$ I-IGF-I (solid lines) or ${ }^{125}{ }^{\text {I-LR }}{ }^{3}$ IGF-I (dashed lines). Pools of wound fluid from six rats $(150 \mu \mathrm{l})$ were mixed and applied to a Superose-12 column equilibrated in PBS ( $\mathrm{pH} 7 \cdot 2)$. Samples were eluted at $0.5 \mathrm{ml} / \mathrm{min}$ with the same buffer. The column was calibrated as described in the legend for Fig. 5. Fractions $(0.5 \mathrm{ml})$ were collected and radioactivity counted on a $\gamma$-counter.

peak in the $150 \mathrm{kDa}$ region had become apparent. By 120 and 240 min there were no peaks of radioactivity in the $150 \mathrm{kDa}$ region and IGF-I-specific radioactivity had become mainly associated with lower molecular weight IGFBPs.

When wound fluid samples taken from rats $5 \mathrm{~min}$ after infusion of ${ }^{125} \mathrm{I}-L R^{3}$ IGF-I were chromatographed, a similar 5 min profile was obtained to that of ${ }^{125}$ I-IGF-I containing wound fluid with a broad region at $50 \mathrm{kDa}$ and a peak at $7.5 \mathrm{kDa}$ (Fig. 6). However, by $30 \mathrm{~min}$ the profile differed from that of ${ }^{125}$ I-IGF-I containing wound fluid, in that two large distinct peaks were observed at $50 \mathrm{kDa}$ and $7 \cdot 5 \mathrm{kDa}$ and no activity occurred in the $150 \mathrm{kDa}$ region. By $120 \mathrm{~min}$ the peaks of radioactivity in the $7 \cdot 5 \mathrm{kDa}$ region had decreased, but the radioactivity in the $50 \mathrm{kDa}$ region had increased by about $25 \%$. A similar profile was observed for the 240 min samples, but a $25 \%$ decrease in 


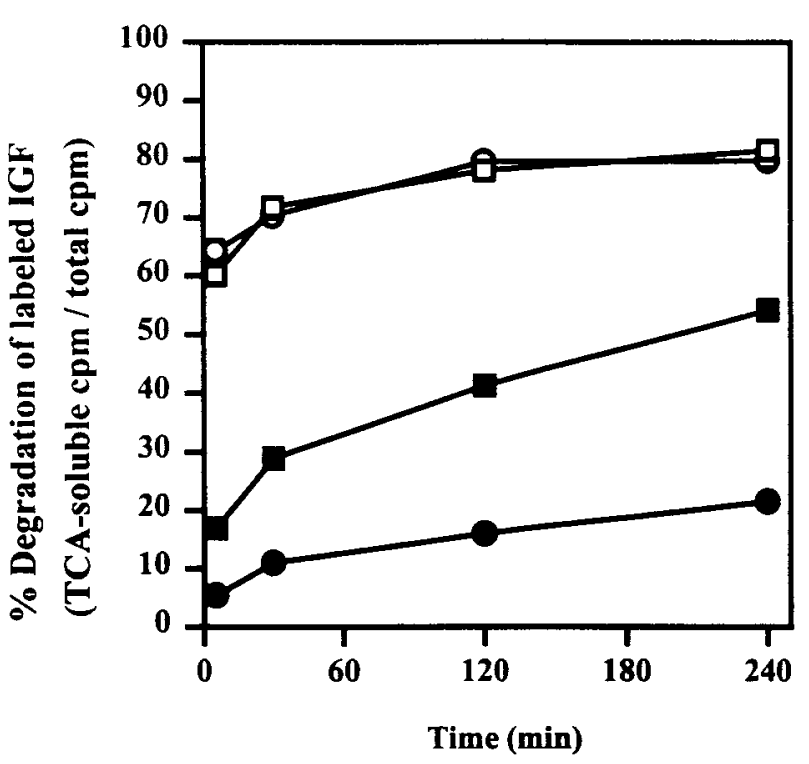

Figure 7 Mean percent degradation of ${ }^{125}$ I-IGF-I and ${ }^{125}$ I-LR ${ }^{3}$ IGF-I in plasma and wound fluid. TCA-soluble radioactivity is expressed as a percentage of total radioactivity at each time point. Data points are means \pm S.E.M. for six animals in each group. IGF-I (circles) and LR ${ }^{3}$ IGF-I (squares) from plasma are represented by closed symbols and from wound fluid by open symbols.

radioactivity in the $50 \mathrm{kDa}$ region had occurred. In the 120 and $240 \mathrm{~min}$ samples more ${ }^{125}$ I-LR ${ }^{3}$ IGF-I total radioactivity was found relative to ${ }^{125}$ I-IGF-I.

\section{Degradation of ${ }^{125}$ I-IGF-I and ${ }^{125}$ I-LR ${ }^{3}$ IGF-I in wound fluid and plasma}

The degradation of growth factors as a function of time after infusion was calculated as a percentage of total plasma or wound fluid radioactivity accounted for by the TCAsoluble fraction (Fig. 7). In plasma, ${ }^{125}{ }^{2}-L_{2}{ }^{3}$ IGF-I was degraded more rapidly and to a greater extent than ${ }^{125}$ I-IGF-I. In contrast, in wound fluid ${ }^{125}{ }^{2}-\mathrm{LR}^{3} \mathrm{IGF}-\mathrm{I}$ and ${ }^{125}$ I-IGF-I were degraded to the same extent. These data suggest that degradation of IGF-I in plasma, or after uptake and release by cells, is inversely related to the binding of IGF-I to plasma IGFBPs. However, the ability of IGF-I to bind IGFBPs does not afford it protection from degradation in wound fluid.

\section{Discussion}

Several observations would suggest that IGF-I is able to leave the vascular compartment and distribute to various tissues (Ballard et al. 1991, Hodgkinson et al. 1991, Prosser et al. 1991, 1992, Bastian et al. 1993, Hill et al. 1997). It has also been demonstrated that IGFBPs have the ability to increase the circulating half-lives of IGFs (Zapf et al. 1986,
Cascieri et al. 1988). Results such as these have led to the proposal that a potential role of the IGFBPs is to control rates of IGF transport from the circulation to extravascular sites (Bastian et al. 1993). Pharmacokinetic studies of IGF-I variant molecules which display reduced association with IGFBPs have been shown to have increased clearance rates, including des(1-3)IGF-I (Ballard et al. 1991), LR ${ }^{3}$ IGF-I (Bastian et al. 1993) and $\left[\mathrm{Gln}^{3}, \mathrm{Ala}^{4}, \mathrm{Tyr}^{15}, \mathrm{Leu}^{12}\right]$-IGF-I (Cascieri et al. 1988).

Examination of day 14 plasma by Western ligand blotting did not reveal any differences in circulating IGFBP profiles between rats implanted with chambers compared with sham control animals. However, this technique does not exclude the possible presence of increased amounts of wound-fluid derived cleaved IGFBP-3 in the chamber-implanted animals. The accelerated clearance of $\mathrm{LR}^{3}$ IGF-I in the plasma of both sham control and chamber-implanted rats is in agreement with previous studies, and may be associated with increased rates of degradation, either in the blood or by tissues where it is degraded and returned to the circulation (Bastian et al. 1993). However, the clearance rates for both peptides in both groups were somewhat lower than in the earlier investigation (Bastian et al. 1993), a difference possibly associated with the use of larger animals in the present study. The key finding was that in rats with increased extracellular volume, clearance rates of IGF-I did not significantly differ to that of sham controls. However, $t_{1 / 2 a}$ was significantly increased, reflecting an alteration in the nature of the central compartment to which IGF-I distributes. In contrast, the clearance rate, volume of distribution and $t_{1 / 2}$ of LR ${ }^{3}$ IGF-I in wound chamber-implanted animals was significantly greater than in sham control animals, which could be attributed to the weaker affinity of LR $^{3}$ IGF-I for IGFBPs, rendering it less confined to plasma. Significantly more LR ${ }^{3}$ IGF-I specific radioactivity was recovered in wound fluid compared with radiolabeled IGF-I, although no difference in the rate of degradation between IGF-I and LR ${ }^{3}$ IGF-I in wound fluid was observed.

These results support the conclusion that transfer of IGF-I peptides from blood to extracellular fluid is inversely related to the ability of the peptides to associate with binding proteins. The results of this comparison are supported by the in vitro studies, which showed that the presence of IGFBPs in experimental medium inhibited transport of IGF-I across an endothelial cell monolayer model of the blood vessel wall, but did not affect transport of LR ${ }^{3}$ IGF-I. Our earlier studies indicate that the movement of free IGF-I across HUVE cell monolayers occurs by a passive non-receptor mediated pathway (Bastian et al. 1997). Current thought acknowledges a number of determinants of passive barrier transport, including intercellular junctions, cell-cell contact, endothelial glycocalyx and the extracellular matrix. Binding of IGF-I to the IGFBPs may add another level to this regulation. It is of interest to note 
that the basal transport of IGF-I alone was significantly greater than that of $\mathrm{LR}^{3}$ IGF-I. This may be because LR $^{3}$ IGF-I is a larger molecule than IGF-I or could arise due to charge differences between the two peptides.

While this study was not designed to calculate the proportional contribution intravascular IGF-I makes to wound fluid IGF-I, it is worth noting that over the $4 \mathrm{~h}$ time course of the study, only some $0.05 \%$ of the administered IGF-I was recovered per milliliter of wound fluid. Other sources of IGF-I during the wound healing process include platelets (Karey \& Sirbasku 1989), macrophages (Rappolee et al. 1988) and the cells of the wound repair response themselves, such as injured endothelial cells (Taylor \& Alexander 1993). Moreover, systemic administration of IGF-I alone, while exerting profound anabolic effects, does not promote repair of incisional (Robertson et al. 1997) or burn wounds (Meyer et al. 1996). A recent study by our group has shown that reversal of steroidinduced catabolism by IGF-I is not accompanied by improvement of excisional wound repair (J G Robertson, unpublished observations). These data would suggest that the surface wound is not an endocrine target of IGF-I.

The IGFBP band pattern of wound fluid and plasma were similar, except that the intensities of the band at approximately $31 \mathrm{kDa}$ and the band at a molecular mass corresponding to IGFBP-3 were reduced in wound fluid compared with plasma (Robertson et al. 1996). A similar IGFBP profile has been described in human skin interstitial fluid (Xu et al. 1995) and human peritoneal dialysate (Kale et al. 1996). Administration of ${ }^{125}$ I-IGF-I to rats implanted with wound chambers followed by neutral gel filtration chromatography of wound fluid samples, revealed that ${ }^{125}$ I-IGF-I was distributed to the lower molecular weight IGFBPs, with smaller amounts associated with the $150 \mathrm{kDa}$ complex and $7.5 \mathrm{kDa}$ region. A similar profile is seen after in vitro incubation of ${ }^{125}$ I-IGF-I with day 14 wound fluid (Robertson et al. 1996). These data, taken together with several reports describing the presence of IGFBP-3 protease activity in extracellular fluids (Xu et al. 1995, Kale et al. 1996, Robertson et al. 1996), imply that extravascular IGF-I exists in a form that is more readily available for interacting with specific IGF tissue receptors. The fact that more $\mathrm{LR}^{3}$ IGF-I was found in a free form in wound fluid relative to IGF-I may mean that it would have even greater accessibility to interact with tissue IGF receptors than IGF-I.

In summary, we have shown that systemically administered IGF-I peptides are transferred from blood to extravascular wound fluid sites, where they exist in forms that may be more readily available to interact with tissue IGF receptors. The pharmacokinetic parameters of LR $^{3}$ IGF-I, but not IGF-I, are affected by changes in the extracellular fluid volume and the rate of transfer of LR ${ }^{3}$ IGF-I from blood to extracellular fluid is dramatically increased over that of IGF-I. The decreased association of $\mathrm{LR}^{3}$ IGF-I with the $150 \mathrm{kDa}$ complex, and the increased rate of delivery of this peptide from the systemic circulation to extracellular fluid pools suggest that this IGF-I analogue may be more active at the wound site.

\section{Acknowledgements}

We are very grateful to Drs Robert Baxter, Eiji Kuto and Dennis Andress plus Diagnostic Systems Laboratories for their kind gifts of IGFBPs. We would also like to thank Ingrid Liepe for help with the isolation and maintenance of HUVE cells and Kerry Penning, Kaylene Pickering, Xenia Georgiou and Gray Robertson for help with the in vivo studies.

\section{References}

Andress DL \& Birnbaum RS 1992 Human osteoblast-derived insulin-like growth factor (IGF) binding protein-5 stimulates osteoblast mitogenesis and potentiates IGF action. Journal of Biological Chemistry 267 22467-22472.

Arany E, Zabel P, Freeman D \& Hill DJ 1993 Elimination of radiolabelled recombinant human insulin-like growth factor binding protein-3 from the circulation, and its distribution amongst organs and tissues in adult male rats. Regulatory Peptides 48 133-143.

Ballard FJ, Knowles SE, Walton PE, Edson K, Owens PC, Mohler MA \& Ferraiolo BL 1991 Plasma clearance and tissue distribution of labelled insulin-like growth factor-I (IGF-I), IGF-II and des(1-3)IGF-I in rats. Journal of Endocrinology 128 197-204.

Bar RS, Boes M, Dake BL, Sandra A, Bayne M, Cascieri M \& Booth BA $1990 a$ Tissue localization of perfused endothelial cell IGF binding protein is markedly altered by association with IGF-I. Endocrinology 127 3243-3245.

Bar RS, Clemmons DR, Boes M, Busby WH, Booth BA, Dake BL \& Sandra A $1990 \mathrm{~b}$ Transcapillary permeability and subendothelial distribution of endothelial and amniotic fluid insulin-like growth factor binding proteins in the rat heart. Endocrinology 127 1078-1086.

Bar RS, Boes M, Clemmons DR, Busby WH, Sandra A, Dake BL \& Booth BA 1990c Insulin differentially alters transcapillary movement of intravascular IGFBP-1, IGFBP-2 and endothelial cell IGFbinding proteins in the rat heart. Endocrinology 127 497-499.

Bastian SEP, Walton PE, Wallace JC \& Ballard FJ 1993 Plasma clearance and tissue distribution of labelled insulin-like growth factor-I (IGF-I) and an analogue LR $^{3}$ IGF-I in pregnant rats. Journal of Endocrinology 138 327-336.

Bastian SEP, Walton PE \& Belford DA 1997 Paracellular transport of insulin-like growth factor-I (IGF-I) across human umbilical vein endothelial cell monolayers. Journal of Cellular Physiology 170 290-298.

Baxter RC 1988 The insulin-like growth factors and their binding proteins. Comparative Biochemistry and Physiology 91 229-235.

Boes M, Booth BA, Sandra A, Dake BL, Bergold A \& Bar RS 1992 Insulin-like growth factor binding protein (IGFBP) 4 accounts for the connective tissue distribution of endothelial cell IGFBPs perfused through the isolated heart. Endocrinology 131 327-330.

Cascieri MA, Saperstein R Hayes NS, Green BG, Chicchi GG, Applebaum J \& Bayne ML 1988 Serum half-life and biological activity of mutants of human insulin-like growth factor I which do not bind to serum binding proteins. Endocrinology 123 373-381.

Cwyfan Hughes SC, Cotterill AM, Molloy AR, Cassell TB, Braude N, Hinds CJ, Wass JAH \& Holly JMP 1992 The induction of specific proteases for insulin-like growth factor-binding proteins following major heart surgery. Journal of Endocrinology 135 135-145. 
Davenport ML, Clemmons DR, Miles MV, Camacho-Hubner C, D'Ercole AJ \& Underwood LE 1990 Regulation of serum insulinlike growth factor-I (IGF-I) and IGF binding proteins during rat pregnancy. Endocrinology 127 1278-1286.

Davenport ML, Isley WL, Pucilowska JB, Pemberton LB, Lyman B, Underwood LE \& Clemmons DR 1992 Insulin-like growth factorbinding protein-3 proteolysis is induced after elective surgery. Journal of Clinical Endocrinology and Metabolism 75 590-595.

Ebeling PR, Jones JD, O'Fallon WM, Janes CH \& Riggs BL 1993 Short-term effects of recombinant human insulin-like growth factor I on bone turnover in normal women. Journal of Clinical Endocrinology and Metabolism 77 1384-1387.

Frost VJ, Macaulay VM, Wass JA \& Holly JM 1993 Proteolytic modification of insulin-like growth factor-binding proteins: comparison of conditioned media from human cell lines, circulating proteases and characterised enzymes. Journal of Endocrinology 138 545-554.

Frost RA, Nachman SA, Lang CH \& Gelato MC 1996 Proteolysis of insulin-like growth factor-binding protein-3 in human immunodeficiency virus-positive children who fail to thrive. Journal of Clinical Endocrinology and Metabolism 81 2957-2962.

Gargosky SE, Walton PE, Owens PC, Wallace JC \& Ballard FJ 1990 Insulin-like growth factor-I (IGF-I) and IGF binding proteins both decline in the rat during late pregnancy. Journal of Endocrinology 127 383-390.

Glasscock GF, Gin KK, Kim JD, Hintz RL \& Rosenfeld RG 1991 Ontogeny of pituitary regulation of growth in the developing rat: comparison of effects of hypophysectomy and hormone replacement on somatic and organ growth, serum insulin-like growth factor-I (IGF-I) and IGF-II levels, and IGF-binding protein levels in the neonatal and juvenile rat. Endocrinology 128 1036-1047.

Green H, Morikawa M \& Nixon T 1985 A dual effector theory of growth-hormone action. Differentiation 29 195-198.

Guler HP, Zapf J, Scheiwiller E \& Froesch ER 1988 Recombinant human insulin-like growth factor-I stimulates growth and has distinct effects on organ size in hypophysectomised rats. Proceedings of the National Academy of Sciences of the USA 85 4889-4893.

Guler HP, Eckardt KU, Zapf J, Bauer C \& Froesch ER 1989 Insulin-like growth factor-I increases glomerular filtration rate and renal plasma flow in man. Acta Endocrinologica 121 101-106.

Hill RA, Flick-Smith HC, Dye S \& Pell JM 1997 Actions of an IGF-I-enhancing antibody on IGF-I pharmacokinetics and tissue distribution: increased IGF-I bioavailability. Journal of Endocrinology 152 123-130

Hodgkinson SC, Spencer GS, Bass JJ, Davis SR \& Gluckman PD 1991 Distribution of circulating insulin-like growth factor-I (IGF-I) into tissues. Endocrinology 29 2085-2093.

Holly JM, Claffey DC, Cwyfan-Hughes SC, Frost VJ \& Yateman ME 1993 Proteases acting on IGFBPs: their occurrence and physiological significance. Growth Regulation 3 88-91.

Hunt TK, Twomey P, Zederfeldt B \& Dunphy JE 1967 Respiratory gas tensions and $\mathrm{pH}$ in healing wounds. American Journal of Surgery 114 302-307.

Jacob R, Barrett E, Plewe G, Fagin KD \& Sherwin RS 1989 Acute effects of insulin-like growth factor I on glucose and amino acid metabolism in the awake fasted rat. Comparison with insulin. Journal of Clinical Investigation 83 1717-1723.

Kale AS, Liu F, Hintz RL, Baker BK, Brewer ED, Lee PDK, Durham SK \& Powell DR 1996 Characterization of insulin-like growth factors and their binding proteins in peritoneal dialysate Pediatric Nephrology 10 467-473.

Karey KP \& Sirbasku DA 1989 Human platelet-derived mitogens. II. Subcellular localisation of insulin-like growth factor-I to the alphagranule and release in response to thrombin. Blood 74 1093-1100.

Lamson G, Giudice LC, Cohen P, Liu F, Gargosky S, Muller HL, Oh Y, Wilson KF, Hintz RL \& Rosenfeld RG 1993 Proteolysis of
IGFBP-3 may be a common regulatory mechanism of IGF action in vivo. Growth Regulation 5 19-28.

Lee CY, Park SK, Yorgin PD, Cohen P, Oh YM \& Rosenfeld RG 1994 Alteration in insulin-like growth factor-binding proteins (IGFBPs) and IGFBP-3 protease activity in serum and urine from acute and chronic renal failure. Journal of Clinical Endocrinology and Metabolism 79 1376-1382.

Meyer NA, Barrow, RE \& Herndon DN 1996 Combined insulin-like growth factor-I and growth hormone improves weight loss and wound healing in burned rats. Journal of Trauma 41 1008-1012.

Prosser CG, Fleet IR, Davis AJ \& Heap RB 1991 Mechanism of secretion of plasma insulin-like growth factor-I into milk of lactating goats. Journal of Endocrinology 131 459-466.

Prosser CG, Baucells MD \& Fleet IR 1992 Transfer of insulin-like growth factors I and II from plasma to lymph in young goats. Experimental Physiology 77 575-585.

Rappolee DA, Mark D, Banda MJ \& Werb Z 1988 Wound macrophages express TGF-alpha and other growth factors in vivo: analysis by mRNA phenotyping. Science 241 708-712.

Robertson JG, Pickering KJ \& Belford DA 1996 Insulin-like growth factor I (IGF-I) and IGF-binding proteins in rat wound fluid. Endocrinology 137 2774-2781.

Robertson JG, Walton PE, Dunshea F, Dunaiski V, Ballard FJ \& Belford DA 1997 Growth hormone but not insulin-like growth factor-I improves wound strength in pigs. Wound Repair and Regeneration 5 168-174.

Sara VR \& Hall K 1990 Insulin-like growth factors and their binding proteins. Physiology Reviews 70 591-614.

Schilling JA, Joel W \& Shurley HM 1959 Wound healing: a comparative study of the histochemical changes in granulation tissue contained in stainless steel wire mesh and polyvinyl sponge cylinders. Surgery 46 702-710.

Schoenle E, Zapf J, Humbel RE \& Froesch ER 1982 Insulin-like growth factor I stimulates growth in hypophysectomized rats. Nature $296252-253$

Taylor WR \& Alexander RW 1993 Autocrine control of wound repair by insulin-like growth factor I in cultured endothelial cells. American Journal of Physiology 265 C801-C805.

Taylor WR, Nerem RM \& Alexander RW 1993 Polarized secretion of IGF-I and IGF-I binding protein activity by cultured aortic endothelial cells. Journal of Cellular Physiology 154 139-142.

Timmins AC, Cotterill AM, Cwyfan Hughes SC, Holly JMP, Ross RJM, Blum W \& Hinds CJ 1996 Critical illness is associated with low circulating concentrations of insulin-like growth factors-I and -II, alterations in insulin-like growth factor binding proteins, and induction of an insulin-like growth factor binding protein 3 protease. Critical Care Medicine 24 1460-1466.

Xu S, Cwyfan-Hughes SC, van der Stappen JWJ, Sansom J, Burton JL, Donnelly M \& Holly JMP 1995 Insulin-like growth factors (IGFs) and IGF-binding proteins in human skin interstitial fluid. Journal of Clinical Endocrinology and Metabolism 80 2940-2945.

Zapf J, Schoenle E \& Froesch ER 1985 in vivo effects of the insulinlike growth factors (IGFs) in the hypophysectomised rat: comparison with human growth hormone and the possible role of the specific IGF carrier proteins. In Proceedings of the CIBA Foundation Symposium, pp 169-187. London: The Bath Press.

Zapf J, Hauri C, Waldvogel M \& Froesch ER 1986 Acute metabolic effects and half-lives of intravenously administered insulin-like growth factors I and II in normal and hypophsectomized rats. Journal of Clinical Investigation 77 1768-1775.

Received 22 February 1999

Revised manuscript received 16 August 1999

Accepted 31 August 1999 